\title{
Social capital in Gellerup
}

\author{
Line Hille Laursen
}

Psychiatric Research Unit West Denmark

\section{Majen Espvall}

Mid-Sweden University

\begin{abstract}
This paper examines the characteristics of two types of social capital; bridging and bonding social capital among the residents inside and outside a marginalized local community in relation to five demographic features of age, gender, geographical origin and years of residence in the community and in Denmark. The data were collected through a questionnaire, conducted in the largest marginalized high-rise community in Denmark, Gellerup, which is about to undergo an extensive community renewal plan. The study showed that residents in Gellerup had access to bonding and bridging social capital inside and outside Gellerup. Nevertheless, the character of the social capital varied considerably depending on age, geographical origin and years lived in Gellerup. Young residents and people who had lived for many years in Gellerup had more social capital than their counterparts. Furthermore, residents from Arab countries had more bonding relations inside Gellerup, while residents from Northern Europe had more bonding relations outside Gellerup.
\end{abstract}

Keywords: Social capital, marginalized communities, Denmark, bonding social capital, bridging social capital 


\section{Introduction}

During the 1960s and 1970s, communities of large-scale high-rise housing estates were built in many countries to meet the after-war housing shortage. At first, these neighbourhoods were considered attractive as they offered modern luxury apartments and green facilities, located on the outskirts of the main cities and provided a calm and relaxing environment for working families. However, in most countries, these new high-rise neighbourhoods enjoyed only a short time of popularity before they became segregated and associated with problematic living conditions, crime, poverty, marginalization and a bad image. In recent years, urban renewal programs have become a key concept underpinning policies which aim to address these problems and to target both the physical and social environment.

Gellerup, a low-income neighbourhood in the city of Aarhus, Denmark, has constantly attracted national and political attention. The community has undergone numerous expensive initiatives to overcome the continuing problems, and lately Gellerup has been characterized as a 'mono-functional ghetto', meaning that the area is without or with limited business activities, cultural and educational institutions (Aarhus Kommune, Brabrand Boligforening, 2007). In 2010, the Danish government approved the most expensive high-rise renewal plan in Danish history (Socialministeriet, 2011), the purpose being to promote and stimulate a development of social capital in the neighbourhood. This is in line with other international renewal projects such as the widescale Revival Project of Bijlmermeer, Amsterdam (see for example Bijlmermeer Museum, 2011, Hellaman \& Wassenberg, 2004 or Projectbureau Vernieuwing Bijlmermeer, 1998), the Moving to Opportunity in the United States (see for example Stal \& Zuberi, 2009) and several others projects. All these projects employed a broad concept of social capital to reduce poverty, ensure economic advancement and improve the image in deprived communities.

In terms of renewal programs, theory based on social capital often constitutes the focal point in the discussions of social cohesion and community development. In general, social capital is defined as a high degree of social interaction within communities and families, civic engagement and associational activity. Social capital is often categorized into bonding and bridging social capital. Bonding social capital is seen as strong ties connecting family members, neighbours, close friends and 
business associates, while bridging social capital represents weaker ties connecting people with different ethnic, cultural and occupational backgrounds (Putnam, 2000). Research on social capital in marginalized communities mainly focuses on bonding and bridging social capital in residential areas. This is explained by the fact that residentially-based networks fulfil an important function in people's everyday lives by providing them with a sense of social belonging, especially for groups such as children, the elderly and others who are likely to spend more time in and close to home. Though, a Swedish study showed that people socialize both inside and outside their neighbourhoods, and in general those inhabitants tend to have stronger ties outside the neighbourhood (Henning \& Lieberg, 1996).

As mentioned earlier, the goal of the renewal plan for Gellerup is to promote and stimulate social capital in the community. In order to be able to evaluate the impact of these efforts at a later stage, it is vital to know how the scope and quality of the social capital look before implementing the plan. The aim of this study is therefore to examine the characteristics of social capital in a marginalized community, Gellerup in Denmark, before the implementation of a renewal plan. The main questions are: 1) To what extent do residents in Gellerup have access to bridging and bonding social capital? 2) What characterizes the bridging and bonding social capital among the residents inside and outside the community of Gellerup? 3) How do age, gender, geographical origin, years of residence in Denmark and years lived in the community of Gellerup, impact on the residents' social capital?

\section{Social capital}

The work of Bourdieu (1986), Coleman (1988) and Putnam (1993; 1995) applied the concept of social capital into widespread use in both academic and political debates. Scholars from different disciplines have adapted the concept to fit a range of theoretical frameworks and utilized the concept in a variety of ways. In general, the sliding implication of social capital is associated with the existence of two complementary areas of application. One area deals with relational capital, rooted in interpersonal relationships, whereas the other area deals with collective capital, which is more related to various forms of social involvement in the local community or in residential areas. Regardless of application, social capital is seen as a network of trusting, reciprocal relationships creating benefits for the members. 
Bourdieu (1986) was interested in the relational implications of social capital and placed emphasis on the individual's non-material forms of capital, such as knowledge capital and symbolic capital. For Bourdieu, social capital was inextricably linked to economic capital, and he was interested in examining how capital in various forms could reproduce inequality and how it was used by the elite. Bourdieu defined social capital as the sum of resources generated through a social network with a mutual exchange of acquaintance and recognition and is seen as a strategic investment which must be maintained and developed (Bourdieu \& Wacquant, 1992). The 'community' was not the primary focus of Bourdieu; rather he was interested in the routine practices of everyday life in relation to what Granovetter (1973) referred to as 'weak ties'. The strength of ties depends, according to Granovetter, on how much time the parties spend together, the degree of emotional intensity and intimacy and the presence of reciprocal exchange.

Coleman (1988) represented a rational actor perspective, and with references to the economists' concept of capital, he emphasized the socio-economic importance of social capital. Social capital should be seen as a result of the individual's targeted actions which require open information channels, obligations, trust and norms of mutual exchange. Furthermore, he put forward a structural-functionalist view arguing that "social capital inheres in the structure of relations between persons and among persons" (Coleman, 1990, p. 303).

With Putnam (1993), the implications of the concept social capital were expanded. In his influential research, he focused on the relationship between civic traditions, democratic participation and associational activity in modern Italy. Putnam (1995) described social capital as: "features of social organization such as networks, norms and social trust that facilitate coordination and cooperation for mutual benefit" (p. 67). Furthermore, Putnam (2000) introduced two types of social capital: 'bonding and bridging'. Bonding social capital was described as exclusive and homogenous groups or networks with strong personal connections (often family and friends). These networks provide emotional support, strengthen identities and facilitate reciprocity and solidarity. Bridging social capital, on the other hand, was described as inclusive for the individual and good for linkage to external assets and information between people. Bridging social capital often occurs when people from different backgrounds engage in social activities in groups and organizations. These social networks can provide opportunities for information, raise interest in the surroundings 
and broaden social horizons. Both bridging and bonding social capital can have powerful social effects on individuals, groups, neighbourhoods and communities. According to de Souza Briggs, (1997) bonding social capital is good for 'getting by' and bridging social capital is crucial for 'getting ahead'. However, bonding and bridging social capital are not purely either-or categories, given that social networks can take different forms. To compare the two different forms of social capital, Putnam (2000) divided them into 'more or less' bridging or bonding social capital. In recent years, scholars have also identified multiple and overlapping characteristics of social capital, resulting in distinctions between for example open and closed networks (Brisson, 2009). Open networks refer to group relationships with open borders, easy to enter and leave, and closed networks refer to a group relationships with closed borders and permanent membership.

The acknowledgement and examination of different characteristics of social capital have led to the criticism that the definition of the concept derives from perspectives assuming that social capital is purely positive. In her studies of unemployed African-American men in St. Louis, Gowan (2010) showed the complexity of social capital. These men lacked bridging social capital. On the other hand, their bonding social capital was very strong, and they helped each other getting by without jobs by involving friends in the local drug industry. The strong relationship within the gang was beneficial for the gang itself; however the drug industry was a key element in the destruction of the local neighbourhood in terms of health, trust and security.

\section{Social capital in marginalized neighbourhoods}

Social problems are often discussed in terms of lack of social capital, and the concept has been used extensively to study inclusion and exclusion in marginalized neighbourhoods where social isolation and poverty are seen as the consequences of a lack of useful social relations. The application of the concept is underpinned by the idea that social capital is the foundation on which social stability is built, and the lack is considered to be a key factor related to personal and societal problems within the community. It also supports a policy perspective saying that an increase in social problems and a decrease in social capital go hand-in- hand. Or vice versa, if social capital in marginalized communities is increased, the social problems will decrease, 
and thus the ability of these communities to respond to opportunities for regeneration and renewal will improve (Middleton, Murie, and Groves, 2005).

However, Middleton and colleagues (ibid) also showed that a lack of bridging social capital is a consequence of social and economic well-being, not the cause of it. This conclusion was based on a study of six neighbourhoods in Birmingham, England. The rich neighbourhoods were more likely to invest in bridging social capital than the residents in marginalized (deprived) neighbourhoods. Furthermore, the study from Birmingham showed that in terms of certain types of bonding social capital, there is no evidence that the poor are better off contrary to what the theory of social capital predicts. The residents in poor neighbourhoods are no more likely to have strong family ties than the residents in the wealthiest neighbourhoods; differences were explained by the fact that economic hardship was an obstacle for participating in social activities due to necessary payment of fees and equipment, which reduces the possibilities to obtain bridging social capital. Middleton et al. (ibid) concluded that the positive emphasis on social capital to target social problems is wrong; rather the social environment can be explained as a product of wealth and demographics, and the unequal distribution of resources will further empower the already wealthy and powerful.

Moreover, other studies have confirmed that community context is a key feature in understanding the genesis of social capital. Cattell's studies (2001) from East London demonstrated that the history of the area, work opportunities, local resources and opportunities for participation played an important role in establishing social bonds and conditions for support exchange. Donoghue and Tranter (2012) explored the association between housing tenure and aspects of social capital in Australia which showed that public tenants, often with low income and low levels of education, expressed lower levels of interpersonal trust and confidence in government institutions.

Policymakers and some academics have presumed that the level of social capital is a key issue distinguishing successful communities from unsuccessful communities. When improving social capital in deprived communities, the ability to address social problems and enhance the physical and social environment will increase. However, currently no research can confirm that the renewal programs have had an impact on personal relations and the existence of social capital. The lack of such relationships can be explained by the various conditions characterizing 
different types of marginalized areas when it comes to residential history, degree of segregation, poverty (Garcia \& Moreno 2011), demographics features and patterns of gender roles (Healy, Haynes \& Hampshire, 2007). As an example, a study evaluating the effectiveness of an urban renewal program in a socially disadvantaged community in Sydney showed no significant changes in the perception of aesthetics, safety and walkability in the neighbourhood or in health status (Jalaludin et al. 2012). Research based upon six case studies in Australia focused on involving residents in neighbourhood renewal. The research highlighted a range of practical barriers and concluded that broader socio-economic issues should be addressed (Wood, 2001). Furthermore, social mix has become a policy objective for disadvantaged neighbourhoods and urban renewal in France, even though research has shown that this policy generally tends to weaken the inhabitants' social capital and transform local forms of coexistence in an unpredictable way (Bacque, Fijalkow, Launay, \& Vermeersch, 2011).

Lack of studies showing the impact of the renewal plans on social capital can be explained by the fact that the concept of social capital has come to mean different things to scholars from different disciplines. Thus, social capital has become less useful as an analytical concept. Some applications define bonding social capital as intracommunity ties, i.e. social capital that exists within a neighbourhood, while bridging social ties are seen as extracommunity ties (ties that exist between residents of different neighbourhoods (Bowen, Marin, Mancini \& Nelson, 2000). This paper stresses the consistent feature of most of the definitions of social capital; i.e. social relationships including social contacts and the exchange of social support. In this study, bonding social capital represents strong social ties between closed groups of people with a common identity, such as families, neighbours or business associates. Whereas, bridging social capital is defined as social ties between and across all kinds of people with different backgrounds, such as geographical origin and social and economic status. Due to the fact that people establish close and more superficial contacts within and outside neighbourhood boundaries, this study investigates four dimensions of social capital; bridging and bonding social capital inside as well as outside the community. This approach stems from the abovementioned trend of using renewal programs to underpin policies by promoting and stimulating social capital in deprived communities. 


\section{Gellerup}

Gellerup encompasses two large-scale high-rise building projects, Gellerup Parken and Toveshøj which were built between 1968-1972 and contains 2,400 apartments. Approximately 7,200 people from about 80 different geographical origins live here (Brabrand Boligforening, 2011). In spite of widescale investments over the years trying to improve the neighbourhood socially, structurally, economically and for safety reasons, Gellerup is characterized as a 'ghetto' where the residents suffer from low employment, lower well-being, a poor knowledge of the Danish language and a higher crime rate than the rest of the country. In Gellerup, 83.7 percent are immigrants and descendants, 53.2 percent are unemployed or lack educational affiliation and 45.6 percent have been convicted (Socialministeriet, 2010:34). These statistics make Gellerup one of the most problematic areas in Denmark.

Because of the continuing problems, Gellerup became a high priority when the Danish government decided to take action and confront the so-called 'parallel societies within ghetto neighbourhoods' in Denmark in 2008 (Socialministeriet, 2010). The debate about a segregated and parallel society in Gellerup focused on the physical segregation from the rest of Aarhus because of the infrastructure and architecture as well as on the continuing poor social functionality (cf. the problematic conditions mentioned above). To solve these problems, the neighbourhood became a political target for a massive change, the purpose being to open up the neighbourhood and create cohesion with the rest of Aarhus city. Instead of being a mono-functional neighbourhood, Gellerup should become multi-functional; i.e. attract business activities, jobs and education (Aarhus Kommune, Brabrand Boligforening, 2007) in order to achieve (at least) the same level of living standard, safety and health etc. consistent with the rest of the municipality (Århus Kommune, 2009).

The renewal plan was developed by the municipality of Aarhus and the housing association Brabrand Boligforening which owns the buildings in Gellerup. The plan was approved by the residents via a democratic process in December 2010, and the residents were encouraged to participate in the further development of the plan. The renewal plan of Gellerup is the largest and most expensive plan to be carried out in Danish history. The plan should be implemented from 2011 to 2030 and includes the demolishing of three blocks making it possible to build new houses with one to two floors for purchase, rent or cooperative housing. This is done to attract and keep people with resources in the neighbourhood. Two blocks will be 
sold, and two blocks will be rented out for business. Schools providing education of short or average length will be moved into the neighbourhood to make education attractive to the young people from the area. The road system will be changed with the purpose of opening up the neighbourhood for others instead of just the residents. Furthermore, a main pedestrian street with shops, restaurants and cultural offers will be laid in the centre of the neighbourhood (Århus Kommune, Brabrand Boligforening, 2010; Brabrand Boligforening, 2011). Within the community of Gellerup the concrete and expected outcomes of the plan are:

- To improve the possibilities of employment and education among the residents by moving workplaces and education into the community.

- To make the area safe and reduce the crime rate by involving young people in social activities.

- To create democratic citizenship by increasing the sense of being part of a group and/or community. This should be achieved by increasing residential community participation and trust in welfare institutions.

- To improve health and increase life expectancy with the purpose of matching the level of the rest of the municipality.

- To create a new image for the area and avoid stigmatization by undertaking physical and architectural changes of the area.

- To increase resident participation in culture and leisure activities to promote positive interaction among children and adults. A special effort will be made to reach young girls.

- To make sure that the composition of residents in the area is mixed (economy, resources and ethnicity) by establishing new neighbourhoods with less public housing. (Århus Kommune, 2009).

\section{Method}

This paper is based on a quantitative study among 100 Gellerup residents between 18 and 78 years old. The participants answered a questionnaire measuring bonding and bridging social capital inside and outside Gellerup. 


\section{Participants}

Due to various traditions and religious views in a community representing residents from more than 80 diverse countries, differences of social capital relating to gender, geographical origin, age, years lived in Denmark and years lived in Gellerup are considered relevant. An overview of the participants, presented in Table 1, shows that males, residents from Arabic countries and young people are slightly overrepresented. We don't know how this sample reflects the total population of residents in Gellerup (data consistent with our categories is not available) though there are reasons to assume that our methods of data collection (contacting residents in a public square) has influenced the participation in the study. For example, during the study it was more difficult to establish contact with women and older residents, which partly can be explained by language barriers and the resistance to talk to strangers. This means that drawing conclusions from this sample about the entire population of Gellerup is limited. In this sample, with only a hundred participants from all over the world, the groups of geographical origin were made depending on what part of a continent the participants came from, for example Eastern Europe including Turkey. Five groups of geographical origin were created (three participants representing Peru, Vietnam and Nepal were excluded in the analyses).

Table 1.

Demographics of participants

\begin{tabular}{|l|c|}
\hline Group categories & $\begin{array}{l}\text { Study } \\
\text { sample (N) } \\
\text { Total }\end{array}$ \\
Gender: & \\
Female & 44 \\
Male & 56 \\
Geographical origin: & \\
Northern Europe & 18 \\
Eastern Europe and Turkey & 12 \\
North Africa & 7 \\
Mid and southern Africa & 22 \\
Arab countries & 38 \\
Other & 3 \\
Age groups: & \\
$18-29$ & 45 \\
$30-49$ & 39 \\
$50-78$ & 16 \\
Years lived in Denmark: &
\end{tabular}




\begin{tabular}{|l|l|}
$0-10$ & 21 \\
$11-20$ & 49 \\
$21-68$ & 30 \\
Years lived in Gellerup: & \\
$0-3$ & 31 \\
$04-10$ & 33 \\
$11-36$ & 36 \\
\hline
\end{tabular}

\section{Measurement}

Williams (2006) has developed and validated an instrument called Internet Social Capital Scales (ISCS). These scales are intended to measure bridging and bonding social capital - in both online and offline internet contexts. The questions included in this instrument measure social integration, access to supportive relationships, experiences of loneliness and reciprocal relationships and conform largely to other instruments examining social network relationships, for example the Social Networks Index (SNI), Interview Schedule for Social Interaction (ISSI) and the Interpersonal Support Evaluation List (ISEL). In this study, the ISCS provided the basis for the construction of a questionnaire suitable to measure the outcome of bridging and bonding social capital inside and outside the community of Gellerup. Like Williams (ibid) our intension was to investigate four dimensions of social capital and therefore the ISCS measurement has provided a basis for the construction of a questionnaire suitable to measure the outcome of bridging and bonding social capital among the residents in and outside the community of Gellerup. The adjusted questionnaire was translated into Danish and contained two parallel scales; one for social capital formed inside Gellerup and one for social capital formed outside Gellerup. Each of these scales had a subscale for bridging and bonding measures, resulting in four subscales with 10 questions each. The outcomes of bridging social capital were measured through questions about receiving external information, being outgoing, having contact with other people and being part of community activities. Bonding social capital scales included access to emotional, financial, cognitive or informative support and experiences of trust and loneliness. The questions were answered by means of a 5 point-Likert scale; i.e. each of the 10-item subscales ranged from 1050. The possible answers were; strongly disagree, disagree, agree, strongly agree, don't know.

In addition, since the community of Gellerup constitutes a broad composition of people from different backgrounds and religions, it was considered relevant to add 
six sub questions to the ISCS scale in order to understand specific characteristics of the social capital in Gellerup. Establishing networks takes time, so to understand the implication of the results we asked how many years the participant had lived in the community and in Denmark. The next two questions dealt with the extent to which family members lived inside or outside Gellerup. This was relevant to assess to what extent bonding social capital was related to family relations or to new social relationships. Finally, we asked to what degree Imams, priests or other religious leaders were consulted in personal or societal matters. These questions were asked in order to examine to what extent religious leaders were seen as personal resources, offering some kind of social support, i.e. providing the community with social capital. In this article, bivariate differences according to demographic features were significance-tested by means of the chi-2 method.

\section{Data collection}

In order to establish contacts with residents in Gellerup, several strategies were considered, e.g. to use organizational gatekeepers such as Brabrand Boligforening and the Residential Information Service. However, after considering different strategies, we finally decided to establish contact with the residents by setting up a table and chairs on a public square in the community. The square was the centre of most local activities, including the library, shopping centre, healthcare centre, community workers etc. This ensured that a broad range of the Gellerup residents passed by this particular square. The setting with table and chairs created curiosity among the residents and made it possible for us to establish contact and present the study. The set up was made on different days and at different hours to reach all kinds of people. One limitation related to this method was that we indirectly excluded residents who did not want to talk to strangers and residents who left the area by car and therefore did not pass by the square.

Applying a Danish questionnaire in a community where most residents did not have Danish as their native language caused some language difficulties, mainly among residents above the age of 45 . Consequently, a professional interpreter in Arabic, Farsi and Turkish was invited to help with translation on a few occasions. This strategy helped reach a group of elderly who otherwise would have been lost in this study. All participants were fully informed of the aim and goal of the study. Furthermore, they were informed that their identity would be kept confidential, and 
that they could withdraw their participation at any given time. The participants were also invited to a presentation of the study results at the local library, (29 September 2011).

\section{Limitations of the study}

To design a questionnaire addressed to a wide variety of groups with different languages was linguistically challenging and there was also a risk that the questions could become culturally anchored. In the following, we will present two examples of statements which were interpreted differently: "I am interested in what people who are different from me think". Many participants automatically assumed that this statement dealt with their reputation in the community, rather than being outgoing. $A$ second example: "If I have problems I know someone who can help me". Some of the respondents considered a social worker as "someone to turn to" if faced with a problem. Other participants had trouble understanding the rhetorical question and were too proud to admit having problems that they needed help with. This means that the results in terms of being outgoing should be interpreted with some caution, and that access to support can also involve help offered by the society.

\section{Results}

In this section, we will present data on the respondents' family relations inside and outside of Gellerup, as well as data on the participants' contacts with religious leaders. With this as background data, the participants' perceptions of access to social capital as a whole will be presented, and subsequently social capital will be divided into bridging and bonding social capital. The results section will end with a presentation and an analysis of the specific questions posed in the study.

To get an idea of the participants' family relations in Denmark and contacts with religious leaders, the questionnaire was, as previously mentioned, enhanced with four sub questions. The results showed that 46 percent had family members living inside Gellerup, and that 65 percent had family members living in Denmark outside Gellerup. Furthermore, about one third of the residents in Gellerup often consulted religious leaders in either personal or societal questions. This could imply that the religious leaders are considered a resource in personal and societal matters. 
Nevertheless, the majority of the residents in Gellerup, about two thirds, did not consult religious leaders in these matters.

Table 2.

Results in percent from four subquestions about family members and contact with religious leaders

\begin{tabular}{|c|c|c|c|c|c|}
\hline$N=100$ & $\begin{array}{l}\text { Strongly } \\
\text { disagree }\end{array}$ & Disagree & Agree & $\begin{array}{l}\text { Strongly } \\
\text { agree }\end{array}$ & Don't know \\
\hline $\begin{array}{l}\text { I have many family members } \\
\text { living in Gellerup }\end{array}$ & 40,0 & 14,0 & 26,0 & 20,0 & 0 \\
\hline $\begin{array}{l}\text { I have many family members } \\
\text { living in Denmark, outside } \\
\text { Gellerup }\end{array}$ & 15,0 & 19,0 & 35,0 & 30,0 & 1,0 \\
\hline $\begin{array}{l}\text { I often contact a religious } \\
\text { leader, imam or priest to } \\
\text { discuss personal problems }\end{array}$ & 48,0 & 25,0 & 12,0 & 14,0 & 1,0 \\
\hline $\begin{array}{l}\text { I often contact a religious } \\
\text { leader, imam or priest to } \\
\text { discuss societal questions }\end{array}$ & 50,0 & 18,0 & 20,0 & 10,0 & 2,0 \\
\hline
\end{tabular}

In Table 3, an analysis of the total outcome of social capital inside and outside Gellerup in relation to all five demographic features is presented. The results showed that gender did not seem to have any impact on social capital. Data referring to geographical origin indicated that residents from Arab countries had the highest level of social capital inside Gellerup while the northern Europeans had the lowest. Whether it is social capital inside or outside Gellerup, people aged between 18 and 29 years had significantly higher values than the other age groups. Number of years lived in Denmark had only little importance; however, the results implied that the longer the residents had lived in Gellerup, the higher their level of social capital inside Gellerup became. 
Table 3.

Social capital within different socio-demographic groups $(N=100)$, mean and $S D$.

\begin{tabular}{|c|c|c|c|c|}
\hline Socio-dem. groups & $\begin{array}{l}\text { Share of sample } \\
\mathrm{N}\end{array}$ & $\begin{array}{l}\text { Total social } \\
\text { capital } \\
(40-200)\end{array}$ & $\begin{array}{l}\text { Social capital } \\
\text { inside Gellerup } \\
\quad(20-100)\end{array}$ & $\begin{array}{c}\text { Social capital } \\
\text { outside } \\
\text { Gellerup } \\
(20-100)\end{array}$ \\
\hline \multicolumn{5}{|l|}{ Gender } \\
\hline Female & 44 & $129.8(.21)$ & $65.1(.12)$ & $64.7(.11)$ \\
\hline Male & 56 & $130.9(.27)$ & $65.7(.15)$ & $61.5(.16)$ \\
\hline \multicolumn{5}{|l|}{ Geographical origin } \\
\hline Northern Europe (NE) & 18 & $126.9(.27)$ & $56.6(.13)^{\star *}$ & $70.3(.17)$ \\
\hline Eastern Europe (EE) & 12 & $129.4(.30)$ & $66.5(.17)$ & $62.9(.17)$ \\
\hline North Africa (NA) & 7 & $126.4(.26)$ & $65.4(.11)$ & $61.0(.16)$ \\
\hline Mid and southern Africa (MA) & 22 & $129.1(.26)$ & $63.9(.16)$ & $65.2(.13)$ \\
\hline Arab countries (AC) & 38 & $133.0(.21)$ & $70.0(.12)$ & $63.0(.13)$ \\
\hline \multicolumn{5}{|l|}{ Age } \\
\hline $18-29$ & 45 & $141.0(.20)^{* *}$ & $70.3(.13)^{* *}$ & $70.7(.12)^{* *}$ \\
\hline $30-49$ & 39 & $121.8(.25)$ & $62.1(.14)$ & $59.6(.14)$ \\
\hline $50-78$ & 16 & $121.6(.25)$ & $60.0(.12)$ & $61.5(.15)$ \\
\hline \multicolumn{5}{|l|}{ Years in Denmark } \\
\hline $0-10$ & 21 & $123.6(.24)$ & $60.7(.15)$ & $62.8(.14)$ \\
\hline $11-20$ & 49 & $136.5(.23)$ & $70.1(.12)$ & $66.3(.14)$ \\
\hline $21-68$ & 30 & $125.4(.24)$ & $61.2(.14)$ & $64.2(.15)$ \\
\hline \multicolumn{5}{|l|}{ Years in Gellerup } \\
\hline $0-3$ & 31 & $127.6(.25)$ & $60.1(.14)^{\star *}$ & $67.4(.16)$ \\
\hline $4-10$ & 33 & $132.9(.22)$ & $65.6(.13)$ & $67.3(.12)$ \\
\hline $11-36$ & 36 & $130.7(.25)$ & $69.9(.13)$ & $60.8(.14)$ \\
\hline
\end{tabular}

Chi square test: ${ }^{* \star} p<0.001 ;{ }^{* *} p<0.01 ;{ }^{*} p<0.05$

To further investigate the differences between social capital inside and outside Gellerup, we tested the relationship between demographic features and access to bridging and bonding social capital. The result confirmed that gender did not have any effect on either bonding or bridging social capital. The results in Table 4 also confirmed earlier results that residents from Arab countries have the highest level of bonding relations inside Gellerup than all other groups. Northern Europeans had more bonding relations outside Gellerup, but significantly lower bridging and bonding social capital inside the community. The northern Europeans' lower level of social capital within Gellerup may be explained by the fact that half of the residents in this group did not have family in Gellerup. In sum, northern European residents in Gellerup mainly interacted with people not living in Gellerup, and residents from Arab countries interacted more inside Gellerup than any other group. 
Table 4.

Bonding and bridging social capital inside and outside Gellerup, ( $N=100)$ mean \& $S D$.

\begin{tabular}{|c|c|c|c|c|}
\hline Socio-dem. groups & $\begin{array}{l}\text { Bonding inside } \\
\text { Gellerup } \\
20-100 \\
\end{array}$ & $\begin{array}{l}\text { Bonding outside } \\
\text { Gellerup } \\
20-100 \\
\end{array}$ & $\begin{array}{l}\text { Bridging inside } \\
\text { Gellerup } \\
20-100 \\
\end{array}$ & $\begin{array}{l}\text { Bridging outside } \\
\text { Gellerup } \\
20-100\end{array}$ \\
\hline \multicolumn{5}{|l|}{ Gender } \\
\hline Female & $31.6(.79)$ & $31.7(.79)$ & $33.4(.72)$ & $33.0(.66)$ \\
\hline Male & $32.2(1.00)$ & $31.4(1.04)$ & $33.4(.79)$ & $33.7(.82)$ \\
\hline \multicolumn{5}{|l|}{ Geographical origin } \\
\hline Northern Europe (NE) & $27.5(.83)^{*}$ & $37.6(.94)^{*}$ & $29.1(.83)^{\star \star}$ & $32.6(.91)$ \\
\hline Eastern Europe (EE) & $34.1(.91)$ & $29.6(.94)$ & $32.3(.88)$ & $33.2(.95)$ \\
\hline North Africa (NA) & $29.8(.92)$ & $27.2(1.10)$ & $35.5(.59)$ & $33.7(.65)$ \\
\hline Mid and southern Africa (MA) & $30.2(1.02)$ & $31.7(.92)$ & $33.6(.86)$ & $33.5(.80)$ \\
\hline Arab countries (AC) & $34.8(.85)$ & $29.6(.84)$ & $35.1(.59)$ & $33.4(.63)$ \\
\hline \multicolumn{5}{|l|}{ Age } \\
\hline $18-29$ & $35.8(.78)^{\star *}$ & $35.7(.77)^{\star *}$ & $34.4(.76)$ & $35.0(.68)^{*}$ \\
\hline $30-49$ & $29.1(.97)$ & $27.5(.95)$ & $33.0(.74)$ & $32.1(.78)$ \\
\hline $50-78$ & $28.3(.74)$ & $29.3(.83)$ & $31.7(.78)$ & $32.2(.83)$ \\
\hline \multicolumn{5}{|l|}{ Years in Denmark } \\
\hline $0-10$ & $30.0(.86)$ & $31.1(.78)$ & $30.6(.87)$ & $31.7(.74)$ \\
\hline $11-20$ & $34.8(.84)$ & $31.9(.89)$ & $35.4(.63)$ & $34.4(.72)$ \\
\hline $21-68$ & $28.8(.95)$ & $31.1(1.10)$ & $32.3(.79)$ & $33.1(.80)$ \\
\hline \multicolumn{5}{|l|}{ Years in Gellerup } \\
\hline $0-3$ & $28.2(.86)^{*}$ & $33.0(.99)^{*}$ & $31.9(.84)$ & $34.3(.81)$ \\
\hline $4-10$ & $32.8(.88)$ & $33.1(.84)$ & $32.8(.67)$ & $34.0(.63)$ \\
\hline $11-36$ & $34.6(.90)$ & $28.6(.92)$ & $35.2(.73)$ & $32.1(.80)$ \\
\hline
\end{tabular}

Chi square test: ${ }^{\star \star \star} p<0.001 ;{ }^{* \star} p<0.01 ;{ }^{\star} p<0.05$

When we tested the outcome of social capital with age, it became evident that age was a significant factor. Residents between 18 and 29 had higher levels of bonding social capital both inside and outside Gellerup as well as higher levels of bridging social capital outside Gellerup than the residents in the age groups 30-49 and 50-78. Several factors could explain these differences. First, the younger generation may have higher levels of bonding because they are second-generation immigrants. Thus, many of them have lived most of their lives in Gellerup, and they were more likely to have parents and family inside the community to provide a close supportive relationship (see Table 2). Second, this generation was more likely to have attended the Danish education system, which may have enabled them to establish close social relationships and bonding and bridging social capital outside Gellerup (in 2008, the primary and lower secondary school in Gellerup, was shut 
down, and the pupils from Gellerup were sent to other schools in the municipality to improve integration).

Number of years lived in Denmark had no effect on bridging and bonding relations, but it was a trend that the social capital, both bridging and bonding, increased after 11-20 years and then decreased with age. Years lived in Gellerup affected the access to bonding relations, but had little effect on bridging relations. $A$ more in-depth analysis of the questions included in the two indexes of bonding and bridging social capital (Table 5) concerning relations in Gellerup, illustrated that 72 percent of the residents had people they trusted and could turn to for help to solve problems. 67 percent had someone to ask for help in important decisions, and 76 percent had someone to turn to if they felt lonely. About 70 percent experienced that interacting with people living in Gellerup makes them feel part of a larger community and make them curious about other places in the world. This indicates that many residents have a relatively large network offering help and support of various kinds, though access to financial support is lower, only 54 percent of the participants have someone to turn to, and 43 percent lacked good job references inside Gellerup.

Regarding bonding social capital outside Gellerup, 71 percent had someone to ask for help to solve their problems, 53 percent had someone to ask for help in important decisions, and 68 percent stated that socializing with people living outside Gellerup made them interested in trying new things. However, many (50 percent) lacked the opportunity to borrow money from someone outside Gellerup, and 44 percent lacked contact to people whom they could use as job references. For many residents, bridging social capital outside Gellerup led to an interest in trying new things (68 percent), but 46 percent of the participants stated that they were not interested in supporting activities outside Gellerup. Results on social capital outside Gellerup showed large variations in the respondents' answers. This variation was presumably due to age differences (Table 4). 
Table 5.

Bonding and bridging social capital $(N=100)$ percentages

\begin{tabular}{|c|c|c|c|c|c|}
\hline Bonding subscale & $\begin{array}{l}\text { Strongly } \\
\text { disagree }\end{array}$ & Disagree & Agree & $\begin{array}{l}\text { Strongly } \\
\text { agree }\end{array}$ & $\begin{array}{l}\text { Don't } \\
\text { know }\end{array}$ \\
\hline There are several people in Gellerup whom I trust to help solve my problems. & 17,0 & 8,0 & 43,0 & 29,0 & 3,0 \\
\hline $\begin{array}{l}\text { There are several people living outside Gellerup whom I trust to help solve my } \\
\text { problems. }\end{array}$ & 16,0 & 15,0 & 37,0 & 27,0 & 5,0 \\
\hline $\begin{array}{l}\text { There is someone who lives in Gellerup I can turn to for advice about making } \\
\text { very important decisions. }\end{array}$ & 16,0 & 13,0 & 40,0 & 27,0 & 4,0 \\
\hline $\begin{array}{l}\text { There is someone who lives outside Gellerup I can turn to for advice about } \\
\text { making very important decisions. }\end{array}$ & 18,0 & 22,0 & 27,0 & 26,0 & 7,0 \\
\hline $\begin{array}{l}\text { There is no one living in Gellerup that I feel comfortable talking to about } \\
\text { intimate personal problems. }\end{array}$ & 21,0 & 24,0 & 35,0 & 18,0 & 2,0 \\
\hline $\begin{array}{l}\text { There is no one living outside Gellerup that I feel comfortable talking to about } \\
\text { intimate personal problems. }\end{array}$ & 16,0 & 19,0 & 36,0 & 25,0 & 4,0 \\
\hline When I feel lonely, there are several people living in Gellerup I can talk to. & 7,0 & 14,0 & 39,0 & 37,0 & 3,0 \\
\hline When I feel lonely, there are several people living outside Gellerup I can talk to. & 12,0 & 19,0 & 34,0 & 31,0 & 4,0 \\
\hline $\begin{array}{l}\text { If I needed an emergency loan of } \$ 500, \text { I know someone living in Gellerup I can } \\
\text { turn to. }\end{array}$ & 34,0 & 20,0 & 17,0 & 23,0 & 6,0 \\
\hline $\begin{array}{l}\text { If I needed an emergency loan of } \$ 500, \text { I know someone living outside Gellerup } \\
\text { I can turn to. }\end{array}$ & 26,0 & 24,0 & 14,0 & 25,0 & 11,0 \\
\hline $\begin{array}{l}\text { The people I interact with, who live in Gellerup, would put their reputation on } \\
\text { the line for me. }\end{array}$ & 20,0 & 14,0 & 28,0 & 21,0 & 17,0 \\
\hline $\begin{array}{l}\text { The people I interact with, who live outside Gellerup, would put their reputation } \\
\text { on the line for me. }\end{array}$ & 21,0 & 17,0 & 31,0 & 13,0 & 18,0 \\
\hline $\begin{array}{l}\text { The people I interact with living in Gellerup would be good job references for } \\
\text { me. }\end{array}$ & 30,0 & 13,0 & 29,0 & 17,0 & 11,0 \\
\hline $\begin{array}{l}\text { The people I interact with living outside Gellerup would be good job references } \\
\text { for me. }\end{array}$ & 27,0 & 17,0 & 34,0 & 14,0 & 8,0 \\
\hline $\begin{array}{l}\text { The people I interact with living in Gellerup would share their last dollar with } \\
\text { me. }\end{array}$ & 31,0 & 19,0 & 26,0 & 10,0 & 14,0 \\
\hline $\begin{array}{l}\text { The people I interact with living outside Gellerup would share their last dollar } \\
\text { with me. }\end{array}$ & 27,0 & 27,0 & 26,0 & 10,0 & 10,0 \\
\hline $\begin{array}{l}\text { I do not know people living in Gellerup well enough to get them to do anything } \\
\text { important. }\end{array}$ & 15,0 & 23,0 & 30,0 & 23,0 & 9,0 \\
\hline $\begin{array}{l}\text { I do not know people living outside Gellerup well enough to get them to do } \\
\text { anything important. }\end{array}$ & 14,0 & 21,0 & 34,0 & 22,0 & 9,0 \\
\hline The people I interact with living in Gellerup would help me fight an injustice. & 14,0 & 12,0 & 35,0 & 20,0 & 35,0 \\
\hline $\begin{array}{l}\text { The people I interact with living outside Gellerup would help me fight an } \\
\text { injustice. }\end{array}$ & 17,0 & 12,0 & 31,0 & 22,0 & 18,0 \\
\hline \multicolumn{6}{|l|}{ Bridging subscale } \\
\hline $\begin{array}{l}\text { Interacting with people living in Gellerup makes me interested in things that } \\
\text { happen outside of my town. }\end{array}$ & 10,0 & 12,0 & 40,0 & 29,0 & 9,0 \\
\hline $\begin{array}{l}\text { Interacting with people living outside Gellerup makes me interested in things } \\
\text { that happen outside of my town. }\end{array}$ & 6,0 & 22,0 & 34,0 & 29,0 & 9,0 \\
\hline Interacting with people living in Gellerup makes me want to try new things. & 11,0 & 15,0 & 51,0 & 18,0 & 5,0 \\
\hline $\begin{array}{l}\text { Interacting with people living outside Gellerup makes me want to try new } \\
\text { things. }\end{array}$ & 9,0 & 15,0 & 44,0 & 24,0 & 8,0 \\
\hline $\begin{array}{l}\text { Interacting with people living in Gellerup makes me interested in what people } \\
\text { unlike me are thinking. }\end{array}$ & 14,0 & 19,0 & 35,0 & 28,0 & 4,0 \\
\hline $\begin{array}{l}\text { Interacting with people living outside Gellerup makes me interested in what } \\
\text { people unlike me are thinking. }\end{array}$ & 13,0 & 25,0 & 34,0 & 24,0 & 4,0 \\
\hline $\begin{array}{l}\text { Talking with people living in Gellerup makes me curious about other places in } \\
\text { the world }\end{array}$ & 5,0 & 21,0 & 26,0 & 43,0 & 5,0 \\
\hline $\begin{array}{l}\text { Talking with people living outside Gellerup makes me curious about other } \\
\text { places in the world. }\end{array}$ & 7,0 & 26,0 & 20,0 & 42,0 & 5,0 \\
\hline $\begin{array}{l}\text { Interacting with people living in Gellerup makes me feel like part of a larger } \\
\text { community }\end{array}$ & 14,0 & 12,0 & 37,0 & 33,0 & 4,0 \\
\hline $\begin{array}{l}\text { Interacting with people living outside Gellerup makes me feel like } \\
\text { larger community. }\end{array}$ & $\mid 13,0$ & 22,0 & 37,0 & 25,0 & 3,0 \\
\hline
\end{tabular}




\begin{tabular}{|c|c|c|c|c|c|}
\hline $\begin{array}{l}\text { Interacting with people living in Gellerup makes me feel connected to the } \\
\text { bigger picture. }\end{array}$ & 14,0 & 16,0 & 33,0 & 19,0 & 18,0 \\
\hline $\begin{array}{l}\text { Interacting with people living outside Gellerup makes me feel connected to the } \\
\text { bigger picture. }\end{array}$ & 12,0 & 19,0 & 32,0 & 20,0 & 17,0 \\
\hline $\begin{array}{l}\text { Interacting with people living in Gellerup reminds me that everyone in the world } \\
\text { is connected. }\end{array}$ & 18,0 & 24,0 & 25,0 & 24,0 & 9,0 \\
\hline $\begin{array}{l}\text { Interacting with people living outside Gellerup reminds me that everyone in the } \\
\text { world is connected. }\end{array}$ & 19,0 & 28,0 & 19,0 & 23,0 & 11,0 \\
\hline I am willing to spend time to support general community activities in Gellerup. & 27,0 & 18,0 & 38,0 & 15,0 & 2,0 \\
\hline $\begin{array}{l}\text { I am willing to spend time to support general community activities outside } \\
\text { Gellerup. }\end{array}$ & 16,0 & 30,0 & 37,0 & 17,0 & 37,0 \\
\hline Interacting with people living in Gellerup gives me new people to talk to. & 18,0 & 20,0 & 44,0 & 14,0 & 4,0 \\
\hline Interacting with people living outside Gellerup gives me new people to talk to. & 8,0 & 18,0 & 50,0 & 21,0 & 3,0 \\
\hline Inside Gellerup, I come in contact with new people all the time. & 21,0 & 28,0 & 37,0 & 12,0 & 2,0 \\
\hline Outside Gellerup, I come in contact with new people all the time. & 14,0 & 32,0 & 32,0 & 20,0 & 2,0 \\
\hline
\end{tabular}

\section{Conclusion}

This study examined the level and the character of social capital in a marginalized community in Denmark. The primary focus was on the residents' access to bridging and bonding social capital inside and outside the community of Gellerup and on how the availability of social capital varied within different socio-demographic groups. Overall, the results showed that the residents of Gellerup, contrary to some beliefs, to a relatively high degree, had access to bonding and bridging social capital inside as well as outside the community.

The political agenda behind the renewal of Gellerup plan was based on the presumption that social capital in marginalized communities, such as Gellerup, attracts people with the same kind of social capital and that the existing social capital within the community is not tradable in the rest of the society. However, our results showed that the concept of social capital is complex; bonding and bridging relations inside the community differ from the meaning of bonding and bridging social capital outside the community and the variation can be profound among the different sociodemographic groups.

In general, about 70 percent of the residents had relations inside Gellerup who they trusted and could turn to for support or if feeling lonely. Furthermore, interacting with people living in Gellerup gave the feeling of being a part of a larger community and made people curious about other places in the world. This indicated that many residents had a relatively large network offering help and support of various kinds, though access to financial support is lower. Only 54 percent of the participants have someone they can turn to for help and 43 percent lack good job references in Gellerup. 
In contrast to many similar studies of social capital in marginalized areas, this study also examined relationships outside the community. The results showed a high level of social capital outside Gellerup; about 70 percent reported that they had someone to ask for help to solve their problems and stated that socializing with people living outside Gellerup made them interested in trying new things. However, only half of the respondents had someone to ask for help in important decisions or with job references, and just as many lacked the opportunity to borrow money from someone outside Gellerup.

An in-depth analysis showed that three out of five demographic features; more explicitly age, origin and years in Gellerup, had an impact on social capital, both inside and outside Gellerup. In particular, in the case of bonding social capital inside the community, differences occurred between group categories. This implied that the level of access to emotional support, ability to mobilize solidarity and access to resources was very uneven. Surprisingly, gender and years lived in Denmark did not prove to have any effect on any dimension of social capital. Age was clearly the most significant factor affecting the level of social capital; young residents had more bonding relations and were more likely to participate in activities outside Gellerup than older residents. This could be explained by several factors; the younger generation are second-generation immigrants, they have lived most of their lives in Gellerup, and many have attended the Danish education system. In contrast, many older residents do not master Danish and are therefore excluded from participating in several social activities. Furthermore, with regard to the adult generations, there is a trend that the longer people live in Gellerup, the lower the level of outside social capital and the higher the level of bonding social capital inside Gellerup becomes. In other words, residents in certain areas transform the social capital towards relationships established in the local community. This phenomenon is by no means only evident in marginalized areas, but is often discussed as causing segregation. However, in more affluent communities, these types of social capital are seen as good and desirable.

We also demonstrated that geographical origin had an impact on the access to social capital. In sum, northern European residents in Gellerup mainly interacted with people not living in Gellerup and residents from Arab countries interacted more inside Gellerup than any other group. However, it remains unknown to what extent people of different origins interact with each other. Most likely, it depends on whether 
the residents have family relations within the community or not. Since interaction between groups of different origins influences how we interpret social capital and examine relationships, bridging as well as bonding social capital across geographic, ethnic and religious boundaries is an important area for future research. This is important for two reasons. First, the notion of social capital should be problematized. Different kinds of networks result in different types of social capital, and the question is what kind of social capital different groups and individuals need to master their everyday lives. Second, further research is vital to build a functional community support structure which can prevent the development of parallel societies within marginalized communities.

Gender did not seem to have any impact on the level or type of social capital. To some extent, these findings were in contrast with general ideas that immigrant women tend to be more isolated than immigrant men and assumptions the that men are more outgoing. One explanation for these divergent results could be that men's social capital is overrated in general, due to the fact that the questionnaire failed to capture women's distinctive contribution to social capital creation. This is in line with feminist critics arguing that the dominant accounts of social capital favour maledominated activities, for example participation in formal networks. Thus, the diffuse informal-network building among women is overlooked, the result being that women's contributions to social capital formation are devalued (Edwards, 2004). The instrument employed in this study was originally validated to examine social capital in online and offline contexts, especially directed towards relatively young people, which could indicate that our questionnaire is more gender neutral.

Most participants in our survey had relationships with other people, both inside and outside Gellerup, offering various forms of exchange and social support. However, important findings in our study demonstrated that the opportunities for financial support and job references were limited. This could pose the risk that the 'one-size-fits-all' approach of social capital can hide differences in economic conditions and poverty. Economic hardship is undoubtedly an obstacle for participating in social activities due to for example necessary payment of fees and equipment. Moreover, limited economic opportunities can also be an obstacle for being part of social support exchange based on reciprocity. The history of the community, work opportunities, local resources and opportunities for participation also play an important role and reflect that the conditions in these kinds of 
neighbourhoods are often the products of systematic forces including discrimination and exploitation (cf. Kubisch, et al., 2002). To build social capital, certain levels of pre-existing resources are required and our results indicate that the challenge concerns poverty and lack of work opportunities, more than the absence of support networks and trusting relationships. As Forrest and Kearns (2001) stressed, social capital is important not for its own sake, but for what one does with it, or what can be attained by it. Building social capital is not enough; scholars and politicians involved in renewal projects, such as the one in Gellerup, need to be aware of the type of social capital they are trying to build. Furthermore, building social capital is only one part of the solution in community renewal programs. Effective community renewal should be supported by a range of other strategies, e.g. programs to build educational aspirations and create jobs. This should be appropriately resourced.

\section{Acknowledgements}

We wish to acknowledge and thank the participants of the study and Ali Joshianpour for donating his time and abilities to interpret during the collection of data. We also wish to thank Professor Masoud Kamali and PhD student Jessica Jönsson for constructive comments on an earlier version of this paper.

\section{References}

Århus Kommune, Brabrand Boligforening (2007). Fra boligområde til bydel. Helhedsplan for Gellerup og Toveshøj. Retrieved from http://filer.aarhuskommune.dk/filer/Gellerup/Helhedsplan\%20Gellerup.pdf

Århus Kommune. (2009). Endelige effektmål for helhedsplan Gellerup/Toveshøj. Retrieved from http://www.helhedsplangellerup.dk/ /media/Subsites/HelhedsplanGellerup/Dokumenter/endelige-effektmaal.pdf

Århus Kommune, Brabrand Boligforening (2010) Helhedsplanen. Retrieved from http://www.helhedsplangellerup.dk/

Bacque, M. H., Fijalkow, Y., Launay, L., \& Vermeersch, S. (2011). Social mix policies in Paris: Discourse, policies and social effects. International Journal of Urban and Regional Research, 35(2), 256-273.

Bijlmermer Museum. (1999). Bijlmermeer Museum. Retrieved from http://www.bijlmermuseum.nl/

Bourdieu, P. (1986). The forms of capital. In: J. G. Richardson (Ed.), Handbook of theory and research for the sociology of education (pp. 241-258). New York: Greenwood.

Bourdieu, P. \& Wacquant, L. J. D. (1992). An invitation to reflexive sociology. Cambridge: Polity Press. 
Brabrand Boligforening. (2011). Fremtidens Gellerup. Retrieved from http://bbbo.dk/Helhedsplan

Brisson, D. (2009). Testing the relationship of formal bonding, informal bonding, and formal bridging social capital on key outcomes for families in low-income neighborhoods. Journal of Sociology and Social Welfare, 36(1), 167-183.

Bowen, G. L., Marin, J. A., Mancini, J. A., \& Nelson, J. P. (2000). Community capacity: Antecedents and consequences. Journal of Community Practice, $8(2), 1-21$.

Cattell, V. (2001). Poor people, poor places, and poor health: The mediating role of social networks and social capital. Social Science \& Medicine, 52(10), 15011516.

Coleman, J. S. (1988). Social capital in the creation of human capital. American Journal of Sociology, 94, 95-121.

Coleman, J. S. (1990). Foundations of social theory. Cambridge: Harvard University Press.

De Souza Briggs, X. (1997). Moving up versus moving out: Neighborhood effects in housing mobility programs. Housing Policy Debate 8(1), 195-234.

Donoghue, J. \& Tranter, B. (2012). Social capital, interpersonal trust, and public housing. Australian Social Work, 65(3), 413-430.

Edwards, R. (2004). Present and absent in troubling ways: Families and social capital debates. The Sociological Review, 60, 1-21.

Forrest, R., \& Kearns, A. (2001) Social cohesion, social capital and the neighbourhood. Urban studies, 38, 2125-2143.

Garcia, M. A.H. \& Moreno R. M. (2011). Neighborhood models and logical location of the immigrant population. The case of the city of Seville. Scripta NovaRevista Electronica de Geografia Y Ciencas Sociales, 15(372), 1-14.

Gowan, T. (2010). What's social capital got to do with it? The ambiguous (and overstated) relationship between social capital and ghetto underemployment. Critical Sociology, 37(1), 47-66.

Granovetter, M. (1973). The strength of weak ties. American Journal of Sociology, 78(6), 1360-1380.

Healy, K., Haynes, M., \& Hampshire, A. (2007). Gender, social capital and location: Understanding the interactions. International Journal of Social Welfare, 16, 110-118.

Helleman, G. \& Wassenberg, F. (2004). The renewal of what was tomorrow's idealistic city. Amsterdam's Bijlmermeer high-rise. Cities, 21(1), 3-17.

Henning, C. \& Lieberg, M. (1996). Strong ties or weak ties? Neighbourhood networks in a new perspective. Scandinavian Housing and Planning Research, 13, 326.

Jalaludin, B., Maxwell, M., Saddik, B., Lobb, E., Byun, R., Gutierrez, R., \& Paszek, J. (2012). A pre-and post-study of an urban renewal program in a socially disadvantaged neighbourhood in Sydney, Australia. BMC Public health, 12: 521.

Kubisch, A. C., Auspos, P., Brown, P., Chaskin, R., Fulbright-Anderson, K., \& Hamilton, R. (2002). Voices from the field II: Reflections on comprehensive community change. Washington, DC, Aspen Institute.

Middleton, A., Murie, A., \& Groves, R. (2005). Social capital and neighbourhoods that work. Urban Studies, 42(10), 1711-1738.

Projectbureau Vernieuwing Bijlmermeer (1998) Bijlmemeer. Retrieved from http://vernieuwdebij|mer.nl/bijlmer11/ 
Putnam, R. D. (1993). Making democrazy work: Civic traditions in modern Italy. Princeton: Princeton University Press.

Putnam, R. D. (1995). 'Bowling alone': America's declining social capital. Journal of Democracy, 6(1), 65-78.

Putnam, R. D. (2000). The collapse and revival of American community. New York: Simon \& Schuster Paperbacks.

Socialministeriet. (2010). Ghettoen tilbage til samfundet, Et opgør med parallelsamfund i Danmark. Rosendahls - Schultz distribution.

Stal, G. Y. \& Zuberi, D. M. (2009). Ending the cycle of poverty through socioeconomic integration: A comparison of Moving to Opportunity (MTO) in the United States and the Bijlmermeer Revival Project in the Netherlands. Cities, 27(1), 3-12.

Williams, D. (2006). On and off the net: Scales for social capital in an online era. Journal of Computer-Mediated Communication, 11(2), 593 -615.

Wood, M. (2001). Resident participation, social cohesion and sustainability in community renewal. Paper presented at the Housing, crime and stronger communities conference Sheffield, Urban Frontiers Program: University of Western Sydney.

\section{Biographical notes}

Line Hille Laursen holds a master degree in behaviour and social science from MidSweden University. Laursen is a research assistant at Psychiatric Research Unit West Denmark with a primary interest in rehabilitation of marginalized groups and the connection with welfare state support and politics.

Majen Espvall is associate professor at the Department of Social Work, MidSweden University. Espvall has in her research been primarily interested in the relationship between the welfare state's formal support system and support offered by informal social network relations in situations of social vulnerability, poverty and poor health. 